\title{
一国立大学病院における時間外の赤血球輸血 一現場で可能な対応を模索して一
}

\author{
緒方 洪之 長谷川康久 塚原 紀子 天野 純 \\ 信州大学医学部附属病院 輸血部
}

(平成 11 年12月 3 日受付)

(平成 12 年 9 月 27 日受領)

\section{RED CELL TRANSFUSIONS AFTER SERVICE HOURS IN A NATIONAL UNIVERSITY HOSPITAL}

Hiroyuki Ogata, Yasuhisa Hasegawa, Noriko Tsukahara and Jun Amano Blood Transfusion Service, Shinshu University Hospital

Many national university hospitals in Japan do not provide physicians with transfusion service at night and on holidays. Physicians in charge are responsible for examination of blood. In this study, we analyzed the cases of red cell transfusion after service hours in our national university hospital for six months, and evaluated what could be done by a limited number of personnel.

On average there was an episode of such transfusion every 2.1 days ( 85 times for 80 patients). Episodes belonged to two groups : the first was 34 operation-unrelated transfusions ( 8 out- and 26 inpatients), and the second was 51 episodes related to surgical operation, including three subgroups: 19 transfusions during or after scheduled operation, 21 for non-gynecologic emergency operation, and 11 for caesarian section which required actually no transfusion. Massive transfusion was necessary for surgery of aortic aneurysms $(3 / 4)$, ischemic heart diseases $(3 / 3)$ and tumors of vertebral column $(2 / 3)$, and for patients of terminal cancer $(1 / 4)$. Type and screen and an on-call system for massive transfusion of more than 5 units would have helped physicians in about $70 \%$ of cases $(52 / 74)$.

Key words : Emergency red cell transfusion, Abbreviated crossmatch, Type and Screen

\section{はじめに}

多くの国立大学病院では, 夜間・休日の緊急輸 血は, 20 年間以上にわたって異常な状態にあっ た.当直制がないために，技師による輸血検査・ 処理のサポートが受けられないのである゙1. 代り に診療科の医師が，慣れない輸血検査を担当する のが通常で，時にはそれが輸血ミスを引き起こし てきだ)3.

国への㗢きかけは，今日まで問題解決につなが らなかった. しかし, 国立大学附属病院輸血部会 議では, 輸血業務の二十四時間体制が目標課題に
なっており, 各大学ごとに対策が模索されている. 最近は，検査部門との協力で二十四時間体制を実 現する病院も増えてきた. 当院でも輸血部からそ の意向を病院長に伝えてあるものの, 実現に至っ ていない. 今後, 進行中の大学改革の過程で, 改 善される可能性が強そうである. しかし, 変革ま での期間にも，時間外輸血は日々おこなわれてお り, 現場にできうる対応の模索も忘れてはなるま い.

そこでこの報告では, 当院での時間外輸血の現 状を把握することを目的とし, 現実的な対応策を 
検討した．ただし，あくまで二十四時間体制実現 までの過渡期の対策と理解していただきたい. ま た，輸血が適正かどうかの検討は，本稿の範囲外 である

\section{対象と方法}

当国立大学病院における時間外の緊急の赤血球 輸血（以下，時間外輸血）とその準備状態を調查 した.期間は 1999 年 1 月から 6 月までの半年間で ある，時間外の依頼・報告書を中心資料とし，輸 血システムから受血情報, 病院の診療情報から入 退院・手術・検査などの情報をえた. 詳細不明で, 担当医に問いあわせた例も少数ある. FFP や血小 板の輸血は対象外とした。

当院は, 19 診療科 680 病床をもつ総合病院で, 輸血業務は輸血部に集中化されている. しかし, 輸血対応の当直制は無い。そこで時間外に輸血が 必要になると，担当医師が，血液センターへの発 注・検查 (血液型判定と交叉試験) - 放射線照射 · 輸血に責任を負う仕組みになっている，その後の 再検査・事務処理・輸血までの製剤の追跡・全過 程のシステムへの入力等は, 輸血部の担当である. このシステムは, 診療側から血液型・輸血情報の 参照が可能である。また, 医師の輸血検査の研修 は，輸血部の責任である.

なお, 輸血件数を単純な基準で決めるのは難し い. 依頼書と輸血の関係が複雑だからである。一 件の輸血に複数の依頼書が使われる例も，また逆
に，一つの依頼書に記入された幾つかの血液が複 数日にわたって別個に輸血された例も多い。ただ し時間外の緊急輸血の場合，その基準は単純で あった。一患者の同一または連続日の「時間外の 依頼書」群を一件とした。時間外に何回か緊急輸 血があった例では，依頼日に一週間以上の間隔が あって容易に件数を判別できた。

\section{結果}

1）時間外の輸血準備は,赤血球輸血全体のどれ ほどの割合をしめるか?

この期間中の赤血球製剤の依頼書 1756 枚中 123 枚（約 7\%）が，時間外に使用されていた．使 用単位数と準備単位数 (200 ml一単位に換算) で みると，それぞれ約 10\%（3332 のうちの 333）と 10.8\%（6636 中の 716）が時間外輸血であった．患 者数では， $11.7 \%$ （686 人中 80 名）に相当する.

なおこの項だけは，データが件数で示されてい ない，先の述べたように，通常の輸血の場合，件 数の算定が非常に困難だったからである.

2）どれほどの頻度か, また, 診療科別の特徴が あるか (表 1)？

この期間中に, 80 名の患者に対して 85 件の赤 血球輸血の準備（うち 26 件は輸血部が担当）が あった. 2.1 日に一回である.

科別に対応するとすれば, 三群に分けるのが適 当のようである.まずI群に, <準備量・使用量と もに非常に多い>整形外科および第二外科（胸部

Table 1 Emergency red cell transfusion and departments

\begin{tabular}{|c|c|c|c|c|c|c|c|c|}
\hline & Department & $\begin{array}{l}\text { Number } \\
\text { of transfu- } \\
\text { sions } \\
\text { episodes }\end{array}$ & $\begin{array}{l}\text { Number } \\
\text { of } \\
\text { patients }\end{array}$ & $\begin{array}{c}\text { Average } \\
\text { volume of } \\
\text { blood prepared } \\
(\mathrm{ml})\end{array}$ & $\begin{array}{c}\text { Average } \\
\text { volume } \\
\text { of blood } \\
\text { transfused }(\mathrm{ml})\end{array}$ & $\begin{array}{c}\text { Maximum } \\
\text { volume } \\
\text { of blood } \\
\text { prepared }(\mathrm{ml})\end{array}$ & $\begin{array}{c}\text { Maximum } \\
\text { volume } \\
\text { of blood } \\
\text { transfused }(\mathrm{ml})\end{array}$ & $\begin{array}{l}\text { Number of } \\
\text { episodes } \\
\text { not requiring } \\
\text { transfusin }\end{array}$ \\
\hline \multirow[t]{3}{*}{ Group I } & Orthopedics & $7(3)$ & 7 & 3,457 & 1,457 & 14,200 & 7,800 & 2 \\
\hline & Surgery (2nd section) & $12(5)$ & 12 & 3,117 & 1,617 & 6,000 & 4,000 & 2 \\
\hline & Surgery (1st section) & $23(8)$ & 20 & 1,652 & 722 & 6,200 & 5,800 & 7 \\
\hline \multirow[t]{4}{*}{ Group II } & Neurosurgery & $5(1)$ & 5 & 1,600 & 840 & 2,000 & 2,000 & 2 \\
\hline & Other surgery sections & $12(5)$ & 12 & 1,050 & 633 & 2,000 & 1,200 & 1 \\
\hline & Pediatrics & $4(1)$ & 2 & 850 & 650 & 2,400 & 1,600 & 0 \\
\hline & Internal Medicine & $11(1)$ & 11 & 850 & 550 & 2,000 & 1,200 & 1 \\
\hline \multirow[t]{2}{*}{ Group III } & Obstetrics & $11(2)$ & 11 & 927 & 0 & 1,800 & 0 & 11 \\
\hline & Total & $85(26)$ & 80 & 1,694 & 791 & 14,200 & 7,800 & 26 \\
\hline
\end{tabular}

( ) Cases in which transfusion technologist prepared the blood. 
Table 2 Emergency red cell transfusion and clinical situations

\begin{tabular}{|c|c|c|c|c|c|c|c|}
\hline $\begin{array}{l}\text { Clinical situation } \\
\text { (departement or place of transfusion) }\end{array}$ & $\begin{array}{l}\text { Number } \\
\text { of } \\
\text { episodes }\end{array}$ & $\begin{array}{c}\text { Average } \\
\text { blood vol., } \\
\text { prepared } \\
\text { ml }\end{array}$ & $\begin{array}{c}\text { Average } \\
\text { blood vol., } \\
\text { transfused } \\
\text { ml }\end{array}$ & $\begin{array}{l}\text { Average } \\
\text { transfusion } \\
\text { rate } \\
\%\end{array}$ & $\begin{array}{l}\text { Prepared } \\
\text { blood vol. } \\
<2,000 \mathrm{ml} \\
\text { n. of cases }\end{array}$ & $\begin{array}{l}\text { Prepared } \\
\text { blood vol. } \\
=2,000 \mathrm{ml} \\
\text { n. of cases }\end{array}$ & $\begin{array}{c}\text { Prepared } \\
\text { blood vol. } \\
>2,000 \mathrm{ml} \\
\text { n, of cases } \\
{[\%]}\end{array}$ \\
\hline A. Transfusion unrelated to surgical operation & $34(8)$ & 1,188 & 812 & 68.4 & 28 & 4 & $2[5.9]$ \\
\hline a-1 out-patients (internal medicine and pediatrics) & $5(1)$ & 1,000 & 440 & 44.0 & 4 & 1 & $0[0.0]$ \\
\hline a-2 out-patients (surgery sections) & $4(0)$ & 1,150 & 700 & 60.9 & 4 & 0 & $0[0.0]$ \\
\hline b-1 in-patients (internal medicine and pediatrics) & $9(3)$ & 844 & 711 & 81.4 & 8 & 0 & $1[11.1]$ \\
\hline b-2 in-patients (surgery sections) & $16(4)$ & 1,450 & 1,013 & 69.9 & 12 & 3 & $1[6.3]$ \\
\hline B. Transfusion related to non-obstetric surgery & $40(0)$ & 2,340 & 970 & 41.5 & 21 & 9 & $10[25.0]$ \\
\hline c after scheduled operation (ward) & $8(0)$ & 1,200 & 325 & 27.1 & 5 & 2 & $1[12.5]$ \\
\hline d during scheduled operation (operation room) & $11(0)$ & 1,273 & 709 & 55.7 & 8 & 3 & $0[0.0]$ \\
\hline e emergency surgery (operation room) & $21(0)$ & 3,333 & 1,390 & 41.7 & 8 & 4 & 9 [42.9] \\
\hline \multicolumn{8}{|l|}{ C. Transfusion related to obstetric surgery } \\
\hline f caesarian section (operation room) & $11(0)$ & 945 & 0 & 0.0 & 11 & 0 & $0[0.0]$ \\
\hline Total & $85(8)$ & 1,699 & 791 & 46.0 & 60 & 13 & 12 [12.9] \\
\hline
\end{tabular}

( ) Number of pediatric cases

中心）と, <平均量は顕著でないもののバラッキ が大きく最多準備・最多使用量が前二者に比肩す る>第一外科（腹部中心）があげられる.

II 群には，輸血準備量がほほ $2,000 \mathrm{ml}$ で足りる 科を集めた. 残りの外科（婦人科を含む）と内科 系がこれにあたる. $2,000 \mathrm{ml}$ を基準にして, 平均準 備・使用量の多目な脳外科もこの群にふくめた.

また産科を第 III 群に独立させた。11 件の緊急 帝王切開に平均約 $1,000 \mathrm{ml}$ を準備しながら全例が 無使用に終わっている点を, 特徵的と考えたから である。

3）どのような状況で, 時間外赤血球の輸血準備 がなされたか（表 2)？

この観点から, 手術 (又は処置) と直接に関連 のない A 群 (34 件 40\%) と，手術に関連した B 群 (40 件 47\%), 緊急帝王切開の輸血の C 群 (11 件 13\%）とに輸血を分けた。

$\mathrm{A}$ 群は, 基本的に外科・内科系ともに起こりう る病棟での輸血で, 準備されれば比較的使用され るやすいのが特徴である (平均使用率 $68.4 \%$ )。一 方, 輸血が必要になった時点をみると, 緊急入院 時には比較的少なく (a 群 9 例), 入院経過中の患 者（b 群 25 例）に多いようである.

手術関連の $\mathrm{B}$ 群は, 外科系に限られ, 入院と同
時に緊急手術がおこなわれる症例 (e 群 21 例) と， 予定手術の延長や再手術で手術室で使用される輸 血 (d 群 11 例) と, 予定術後に病棟で輸血が必要 になる場合（c 群 8 例）とから成っている.

$\mathrm{A} \cdot \mathrm{B}$ 群を比較すると, 手術関連の B 群では A 群の約二倍の血液が準備されていた $(2,340 \mathrm{ml}$ と $1,188 \mathrm{ml})$ 。ただし使用率は低く $(41.5 \%)$, 両群の 平均使用量に大差はない $(970 \mathrm{ml}$ と $812 \mathrm{ml})$. また 準備量が $2,000 \mathrm{ml}$ 以上の例は，A 群で $18 \%$ (34 例中 6 例) 未満なのに, B 群では $47 \%$ (40 例中 19 例）を越えている．なかでも e 群の緊急手術では 約 $62 \%$ （21 例中 13 例）に達していた。なおここ の $2,000 \mathrm{ml}$ の区切りに医学的な根拠はない. くど の量から当部が診療科を助けられるかを考慮した $>$ 経験的・意図的な区切りである.

4）時間外に大量の赤血球製剂を準備したのは どんな症例か?

$2,000 \mathrm{ml}$ 以上を準備した 25 症例の詳細を，表 3 にまとめた. 手術関連の B 群のうち緊急手術の症 例（e 群 13 例）は, 胸部と腹部の大動脈瘤, 虚血 性心疾患, 脊髄腫瘍がその大半を占めている（10 例). しかも, その 8 例で $4,000 \mathrm{ml}$ 以上大量の血液 が準備されていた.

それに比べて，B 群でも予定手術に関連した c, 
Table 3 Emergency cases withr more than 2,000 $\mathrm{ml}$ of blood prepared

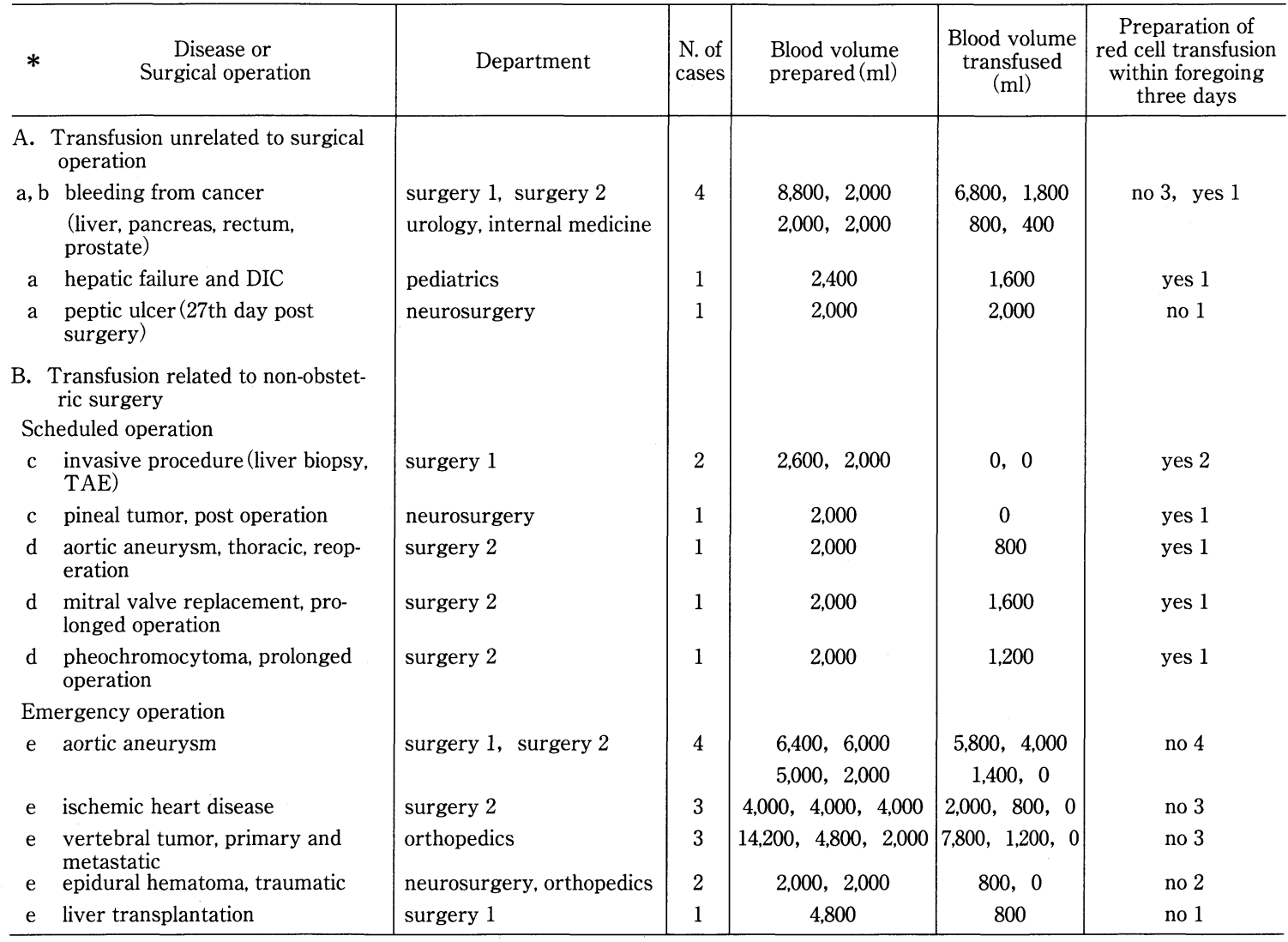

* Same grouping as in Table 2.

$\mathrm{d}$ 群では, 手術と無関係の $\mathrm{A}$ 群とともに準備量が 少なくて, $2,000 \mathrm{ml}$ の例が合計 12 例中の 9 件を占 めていた.ただし，手術と関係のない輸血（A 群）でも，悪性腫瘍の末期の出血には注意すべき であろう。これが $\mathrm{A}$ 群の中心を成しており $(6$ 例中 4 例 $)$, 直腸癌で $6,800 \mathrm{ml}$ を病棟で輸血したの 患者もあったからである。

\section{考察}

これらの結果から，輸血部の現場で時間外輸血 の何ができるかを検討してみた，ただし緊急帝王 切開の 11 例を除く残りの 74 例の検討である. 帝 王切開では血液が全く使用されておらず，無使用 を前提とした準備とみなしたからである.

まず, 時間外輸血から交叉試験を省くとしたら， どこまで可能であろうか. 当院の輸血検査は, 血 液型判定, 交叉試験と抗体スクリーニングから
なっている，つまり，予定手術関連の 19 例 (表 2 , B-c 及び-d 群)ではすでにスクリーニングがすん でおり,さらに病棟輸血のうち入院経過中であっ た 25 名 (同，A-b 群) では，前もってのスクリー ニングが可能だったとも考えられる．もし全例で 可能であったなら，予定手術の 19 名と併せると， 全 74 例の約 6 割で交叉試験ぬきで輸血できたこ とになろう。ただしこれには，どの範囲の入院患 者を予めスクリーニングすべきか，検討が必要で ある. 今回の調查では, 結論は得られない. しか し，悪性腫瘍の進行した患者は全員，スクリーニ ングが必要と考えている.

さらに，これらの例で type and screen のみの 輸血が適切かどうかも検討すべきであろう．厚生 省の指針などでは4)5)，この手法の応用は術中輸 血の可能性の低い待機的手術に関連して述べられ 
ている. 病棟での輸血や多量の術中輸血への応用 については, 否定も肯定もされていない. しかし, 不慣れな医師による輸血ミスの頻度や2)3), 他国 の経験的な危険頻度 ${ }^{6 / 7)}$ を考えあわせると, 専門の 技師による type and screen の報告に基づく輸血 は, 医師の交叉試験による輸血より充分に安全で はあるまいか（もちろん ABO 血液型の再確認は 必須である).さらに, 当部でも交叉試験とスク リーニングを十数年間併用してきて, 前者で検出 されて後者で捕まらない「臨床的に意義のある抗 体」には一件も遭遇していない（抗 A 抗体をもつ A2 型等を除く).ただし，この対策で交差試験を 省くなら, 担当医による血液型の判定と, 電算機 中の患者の血液型情報との照合を必須条件とすべ きであろう。

次に, あらかじめ抗体スクリーニングを利用で きない例（a 群と e 群の合計 30 例）で診療科の負 担を軽減するには, どう対処すべきであろうか. 少数の輸血部職員が日常勤務をこなしながらとな ると, 制限つきの on call 制が限界であろう. 経験 によると医師の多い大学病院では, 制限がないと 緊急の範囲をこえた依頼の対応に苦しむからであ る.

制限として，病名を限定した緊急手術がまず考 えられる, 例えば, 大動脈瘤, 虚血性心疾患, 脊 髄腫瘍の緊急手術のみを選ぶ方法があろう。この 三疾患では大量の輸血準備を必要としていて（表 3), 輸血部の協力が必要と考えられる.

さらに準備量で制限する方法もあろう。例えば 準備が $\lceil 2,000 \mathrm{ml}$ をこす」例に on call を限定してお けば, 前述の三疾患の大半とともに病棟での大量 輸血にも対応できる。これなら, 平均して 2 週間 に一回の対応でよい. 技師にゆとりがあれば，基 準を「2,000ml 以上」にできる.これなら毎週一回 である.

また, 照射済みの血液の備蓄を $2,000 \mathrm{ml}$ に設定 し, 輸血必要量が備蓄で不足する事態にのみ対応 する方法もあろう。これなら大量輸血にも血液照 射にも対応が可能である.

時間外の輸血の基本は，技師の当直制にある.
本稿は, その根本的な変革を論ずる材料をもたな い.また, 緊急輸血の適正についても, 最近の視 点からの再検討が必要であるにもかかわらず8), 言及することがなかった. あくまでこの報告の目 的は, 根本的な対応までの過渡的な手段の検討に ある。

<付記>

99 年に初稿を書き終えたあと, 状況が変化し た. 上記案の修正版を, 院内療法委員会の決定を えて，実施に移したのである. 2000 年 1 月から， 時間外輸血に備えて入院患者の type and screening を診療科にすすめる一方, $2,800 \mathrm{ml}$ を越す輸血 準備に限って on call 制を開始した.なおさらに 10 月から, on call の下限が本稿案と同じ「 $\lceil 2,000 \mathrm{ml}$ を越す量」に減少される。他方，二十四時間体制 の道筋はまだ見えていない，過渡期の努力はまだ まだ続くようである，その試みの結果は，機会が あれば別に報告したい.

\section{文献}

1）山梨医科大学輸血部: 第三十回全国国立大学病 院輸血部会議資料, 1998 , 第 2 表.

2）児玉 健：全国国立大学病院における時間外輸 血業務の実態, 日本輸血学会雑誌, 42 (6) : 272278, 1996.

3）倉田義之, 清川知子, 青地 寛, 永峰啓丞, 林 悟, 押田真知子: 近畿 12 大学病院における過去 5 年間の $\mathrm{ABO}$ 血液型異型輸血の現状と防止対策一 アンケート調查報告一, 日本輸血学会雑誌, 45 (2) : 200, 1999.

4）厚生省医薬安全局：血液製剂の使用指針，血液製 版調査機構編, 血液製剤の使用にあたって, 薬業 時報社, 東京, 1999, 11.

5) American Association of Blood Banks, Technical Manual, 13th Ed., 1999, 382-383.

6) Schulman IA, Nelson JM, Saxena S, et al. : Experience with the routine use of an abbreviated crossmatch. Am J Clin Path 82 : 178-181, 1984.

7) Schulman IA, : The risk of an overt hemolytic transfusion reaction following the use of an immediate spin crossmatch. Arch Pathol Lab Med 114, 412-414, 1990.

8) Hebert PC, Wells G, Blajchman MA, et al. : A multicenter, randomized, controlled clinical traial of transfusion requirements in critical care. $\mathrm{N}$ Engl J Med 340 : 409-417, 1999. 